CASSOWARY volume 5 (1) Januari 2022: 35 - 47

ISSN : 2614-8900

E-ISSN : 2622-6545

Program Pascasarjana Universitas Papua, https://pasca.unipa.ac.id/

\title{
Analisis emisi gas buang kendaraan bermotor (angkutan umum penumpang) di Kabupaten Manokwari
}

\author{
Hendri Irnawan Saputro ${ }^{1)}$, Eko Agus Martanto ${ }^{1)^{*}}$ dan Umi Yuminarti ${ }^{1)}$ \\ ${ }^{1)}$ Program Studi Ilmu Lingkungan, Program Pascasarjana, Universitas Papua, Jalan \\ Gunung Salju, Amban, Manokwari, Papua Barat, 98314, Indonesia \\ *Email: e_a_martanto@yahoo.com
}

Disubmit: 12 April 2021, direvisi: 03 Januari 2022, diterima: 20 Januari 2022

Doi: https://doi.org/10.30862/casssowary.cs.v5.i1.100

\begin{abstract}
Transportation is very instrumental directly in the process of development, due to the transportation community easily perform the displacement from a site to the other, thus accelerating the growth of the economy in large cities and villages. However, such transport is not feasible and provide negative impact to the environment in the form of air pollution. The purpose of research was to (1). analyse large concentrations of $\mathrm{CO}$, $\mathrm{HC}, \mathrm{CO}_{2}$ and $\mathrm{O}_{2}$ in the emission gas exhaust, (2). analyse the effect of emission gas exhaust of vehicles public transport, and (3) analyse the influence of the characteristics of public transport vehicles against the concentration of $\mathrm{CO}$ and $\mathrm{HC}$ test emissions existed in the District Manokwari. The research was a kind of quantitative research where all the data needed for the analysis were obtained directly. The data directly required were data obtained by measuring the amount of emission, the characteristics of the operational public transport, interviews, and analysis of regression linear multiple by using SPSS 25 . The results of the study showed that the average amount of emission gas exhaust of public transport vehicles in the District Manokwari is $\mathrm{CO}$ at $2.13 \%, \mathrm{HC}$ at $534.60 \mathrm{ppm}, \mathrm{CO}_{2}$ at $12.96 \%$ and $\mathrm{O}_{2}$ at $2.71 \%$. Most of the public transport operating in the city of Manokwari issued emission gas exhaust exceeded the threshold limit that has been set and has the potential to pollute the air or do not pass the test of emissions by $63.50 \%$ and only $36.5 \%$ in transport public passed the test of emission gas exhaust. In addition, the results of the test emission coefficient of the regression were simultaneously throughout the variables affecting the emission of $\mathrm{CO}$ and $\mathrm{HC}$.
\end{abstract}

Keywords: Transportation, vehicle emissions test, characteristics of the vehicle.

\section{PENDAHULUAN}

Transportasi sangat berperan secara langsung dalam proses pembangunan, karena dengan adanya transporttasi masyarakat mudah melakukan perpindahan dari suatu tempat ke tempat lain, sehingga mempercepat pertumbuhan ekonomi didesa dan dikota besar. Namun demikian transportasi yang tidak layak dapat memberikan dampak buruk bagi lingkungan berupa pencemaran udara (Tanan, 2011).

Indonesia memiliki tingkat kepadatan penduduk yang tinggi sehingga mengakibatkan naiknya jumlah kendaraan bermotor. Hal ini berdampak pada kompleksnya permasalahan yang disebabkan pencemaran udara yang 
dapat mengganggu kesehatan manusia, sejalan dengan penelitian Hickman (1999), yang menyatakan bahwa di negara-negara Eropa peningkatan jumlah kendaraan sebanding dengan jumlah penduduk.

Berdasarkan evaluasi Kementerian Lingkungan hidup telah terjadi penurunan kualitas udara perkotaan, dimana sektor transportasi mendominasi sekitar $90 \%$ polusi udara dari sektor transportasi seperti emisi gas buang pada kendaraan bermotor. Untuk mengantisipasi hal tersebut, Pemerintah Indonesia membuat dan mengeluarkan UndangUndang (UU) Nomor 22 tahun 2009 tentang Lalu Lintas dan Angkutan Jalan kepada pengguna kendaraan bermotor yang menghasilkan polusi udara, guna menekan jumlah pencemaran udara yang sangat besar yang menggunakan bahan bakar minyak (bahan bakar fosil) kepada setiap pengguna kendaraan bermotor.

Pencegahan dan penanggulangan lingkungan hidup sebagai akibat masalah transportasi diatur dalam pasal 29 ayat (1) UU Nomor 22 tahun 2009, yang menyebutkan "Untuk menjamin kelestarian lingkungan dalam setiap kegiatan di bidang lalu lintas dan angkutan jalan harus dilakukan pencegahan dan penanggulangan pencemaran lingkungan hidup untuk memenuhi ketentuan baku mutu lingkungan sesuai dengan ketentuan peraturan perundang undangan" (Republik Indonesia, 2009). Sesuai dengan peraturan tersebut pasal 5 ayat 2 dijelaskan bahwa setiap kendaraan bermotor yang dioperasikan di wilayah daerah wajib dilakukan uji emisi gas buang berkala kendaraan bermotor. Masa berlaku uji emisi gas buang tersebut berlaku selama 6 bulan.

Namun terdapat beberapa negara yang memiliki standar emisi tidak terlalu ketat, hanya mengukur empat unsur dalam gas buang yaitu senyawa $\mathrm{HC}, \mathrm{CO}$,
$\mathrm{CO}_{2}$ dan $\mathrm{O}_{2}$, termasuk Indonesia (Gunandi, 2010).

Pada saat ini transportasi khususnya angkutan umum penumpang maupun angkutan umum barang di Kabupaten Manokwari jauh dari kondisi layak. Bertambahnya jumlah kendaraan bermotor yang beroperasi, menyebabkan pencemaran udara (polutan) semakin meningkat, sehingga mengakibatkan menurunnya kualitas hidup Manusia (Arafah, et al, 2013). Berdasarkan data Badan Pusat Statistik (BPS) Kabupaten Manokwari, jumlah kendaraan dari tahun ke tahun di Kabupaten Manokwari mengalami kenaikan. Adapun jumlah kendaraan angkutan umum penumpang di Kabupaten Manokwari sampai dengan tahun 2019 berjumlah (712) unit. Tujuan penelitian ini adalah untuk menganalisis emisi gas buang angkutan umum yang beroperasi di Kabupaten Manokwari, Provinsi Papua Barat.

\section{METODE PENELITIAN}

\section{Waktu dan Tempat}

Penelitian dilaksanakan selama kurang lebih 9 bulan dan pengolahan data selama kurang lebih satu bulan, terhitung mulai Juni 2020 s/d April 2021 di Terminal Wosi Kabupaten Manokwari.

\section{Alat dan Bahan:}

Alat uji emisi Portable Gas Analyzer, kuisioner, kendaraan uji, laptop, kamera.

\section{Metode dan Teknik Penelitian}

Penelitian ini merupakan bersifat kuantitatif. Data yang dibutuh-kan untuk analisis diperoleh secara langsung. Penentuan sampel kendaraan angkutan umum dalam penelitian ini dilakukan secara insidental. Data yang diperlukan diperoleh secara langsung yaitu data hasil pengukuran besaran emisi, 
karakteristik operasional angku-tan umum, dan wawancara.

\section{Variabel Pengamatan}

Variabel yang diukur untuk mengetahui hubungan antara jenis kendaraan angkutan umum berpenggerak cetus api terhadap tingkat pencemaran udara.

1. Parameter hasil uji emisi adalah $\mathrm{CO}$, $\mathrm{HC}, \mathrm{CO}_{2}$, dan $\mathrm{O}_{2}$.

2. Karakteristik kendaraan angkutan umum kapasitas silinder. Panjang perjalanan, sistem pembakaran diukur berdasarkan penggunaan tipe mesin. Full injection= 2, Karburator $=1$. Umur kendaraan di ukur berdasarkan usia kendaraan yang dihitung sejak tahun pembuatan hingga saat penelitian dilakukan. Perawatan kendaraan terdiri atas;

\begin{tabular}{cc}
\hline Kategori Perawatan & Rentang Waktu \\
\hline Sering & $1-<3$ bulan \\
Kadang-kadang & $4-<6$ bulan \\
Jarang & $6-<8$ bulan \\
Tidak Pernah & - \\
\hline
\end{tabular}

\section{Analisis Data}

Analisis data untuk menjawab tujuan pertama dilakukan menggunakan tabulasi hasil uji emisi gas buang pada kendaraan angkutan umum. Tujuan kedua melihat tingkat pencemaran emisi gas buang pada kendaraan angkutan umum berpenggerak cetus api. Data lapangan dibandingkan dengan data ambang batas yang sudah ditetapkan oleh Peraturan Menteri Negara Lingkungan Hidup nomor: 05 Tahun 2006 sehingga diperoleh data kendaraan yang lolos uji dan tidak lolos uji emisi (Menteri Lingkungan Hidup Republik Indonesia, 2006).

Tujuan ketiga pengaruh karakteristik kendaraan terhadap kandungan emisi $\mathrm{CO}$ dan $\mathrm{HC}$, dianalisis menggunakan regresi linier, model hubungan antara emisi gas buang dengan karakteristik kendaraan mengikuti fungsi persamaan sesuai dengan persamaan menurut Ghozali (2005).

$$
\begin{gathered}
\mathrm{Y}=\mathrm{b}_{1} \mathrm{X}_{1}+\mathrm{b}_{2} \mathrm{X}_{2}+\mathrm{b}_{3} \mathrm{X}_{3}+\mathrm{b}_{4} \mathrm{X}_{4}+\mathrm{b}_{5} \\
\mathrm{X}_{5}+\mathrm{e}
\end{gathered}
$$

dimana :

$\mathrm{Y}=$ Emisi gas buang $(\mathrm{CO}$ dan $\mathrm{HC})$

$\mathrm{X}_{1}=$ Kapasitas silinder

$\mathrm{X}_{2}=$ Panjang perjalanan

$\mathrm{X}_{3}=$ Sistem Pembakaran

$\mathrm{X}_{4}=$ Umur kendaraan

$\mathrm{X}_{5}=$ Perawatan kendaraan

$\mathrm{e}=$ variabel pengganggu

$b_{1-5}=$ Koefisien regresi variable karakteristik kendaraan $\left(\mathrm{x}_{1}-\mathrm{x}_{5}\right)$.

Digunakan uji-F untuk mengetahui tingkat signifikan pengaruh variable bebas $\mathrm{X}$ (karakteristik kendaraan) terhadap variabel tidak bebas Y (emisi gas buang) secara bersama-sama (simultan). Uji-t digunakan untuk mengetahui tingkat signifikan pengaruh variable bebas $X$ terhadap variable tidak bebas Y secara terpisah (partial). Adapun hipotesis yang untuk menjawab tujuan kedua adalah:

$\mathrm{H}_{\mathrm{o}}=$ Variabel-variabel bebas: kapasitas silinder, panjang perjalanan, sistem pembakaran, umur kendaraan, perawatan kendaraan tidak berpengaruh signifikan terhadap variable terikat emisi gas buang.

$\mathrm{H}_{1}=$ Variabel-variabel bebas: kapasitas silinder, panjang perjalanan, sistem pembakaran, umur kendaraan, perawatan kendaraan berpengaruh signifikan terhadap variable terikat emisi gas buang.

Dengan menggunakan angka probabilitas signifikasi maka :

a. Probabilitas signifikansi $>0,05$, terima $\mathrm{H}_{0}$ dan tolak $\mathrm{H}_{1}$

b. Probabilitas signifikansi $<0,05$, tolak $\mathrm{H}_{0}$ dan terima $\mathrm{H}_{1}$. 


\section{HASIL DAN PEMBAHASAN}

\section{Karakteristik Kendaraan Umum}

Merek Produsen Mobil Penumpang

Hanya ditemui 3 (tiga) merek produsen mobil yaitu Toyota, Suzuki dan Avanza. Hal ini berarti mayoritas merek produsen mobil penumpang yang beroperasi di Manokwari didominasi oleh ketiga merek tersebut (Gambar 1).

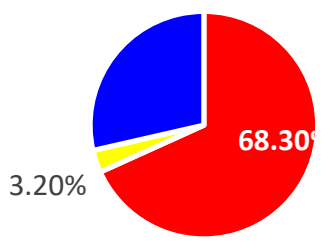

\section{- SUZUKI $\backsim$ MITSUBISHI - TOYOTA}

Gambar 1. Merk Produsen Mobil

Gambar 1 memperlihatkan mayoritas merek mobil penumpang berbahan bakar cetus api yang terlibat dalam penelitian ini adalah mobil penumpang dengan merk Suzuki (43 unit), Toyota (18 unit) dan Mitsubishi (2 unit).

\section{Kapasitas Silinder}

Mayoritas silinder kendaraan umum berbahan bakar bensin yang menjadi sampel dalam penelitian ini berkapasistas $<2.000$ CC (62 kendaraan) sedangkan antara $2.000-3.000 \mathrm{CC}$ hanya satu kendaraan (Tabel 1). Data pada Tabel 1 memperlihatkan mayoritas kendaraan penumpang yang beroperasi di Manokwari berkapasitas silinder < 2000 CC dan mayoritas bermerek Suzuki. Meskipun demikian terdapat 1 kendaraan bermerek Mitsubishi yang memiliki kapasitas silinder antara 2.000 - 3.000 CC. Pada kendaraan berbahan bakar bensin, kapasitas silinder dan proporsi campuran antara bahan bakar dan gas berpengaruh terhadap kesempurnaan proses pembakaran (Syahrani, 2006).

\section{Panjang Perjalanan}

Karakteristik panjang perjalanan yang telah ditempuh oleh kendaraan sesuai dengan hasil pembacaan pada odometer mobil (Tabel 2). Data panjang perjalanan menunjukan bahwa semakin tua umur kendaraan memiliki jarak tempuh yang semakin panjang. Hal ini akan berdampak pada besarnya emisi $\mathrm{CO}$ dan $\mathrm{CO}_{2}$ yang dihasilkan. Karena semakin panjang perjalanan suatu kendaraan maka konsentrasi emisi $\mathrm{CO}$ dan $\mathrm{CO}_{2}$ yang dihasilkan semakin meningkat (Wayunadjati, 2011).

\section{Sistem Pembakaran}

Jumlah mobil penumpang berdasarkan sistem pembakaran (Tabel 4.3). Mayoritas sistem pembakaran kendaraan umum yang menjadi sampel memiliki sistem pembakaran injeksi (52 unit). Sedangkan yang memiliki sistem pembakaran karburator sebanyak 11 unit (Tabel 3).

$\underline{\text { Tabel 1. Merek dan Kapasitas Silinder Kendaraan Penumpang }}$

\begin{tabular}{ccccc}
\hline \multirow{2}{*}{ No } & \multirow{2}{*}{ Merek } & \multicolumn{3}{c}{ Kapasitas Silinder } \\
\cline { 3 - 5 } & & $<2000 \mathrm{CC}$ & $2000-3000 \mathrm{CC}$ & $>3000 \mathrm{CC}$ \\
\hline 1 & Suzuki & 43 & - & - \\
2 & Toyota & 18 & - & - \\
3 & Mitsubishi & 1 & 1 & \\
\hline \multicolumn{2}{l}{ Jumlah } & 62 & 1 & \\
\hline
\end{tabular}


Tabel 2. Panjang Perjalanan Kendaraan

\begin{tabular}{|c|c|c|c|c|c|c|c|c|}
\hline \multirow{2}{*}{ No } & \multirow{2}{*}{\multicolumn{2}{|c|}{ Panjang Perjalanan (KM) }} & \multicolumn{5}{|c|}{ Umur (Tahun) } & \multirow{2}{*}{ Jumlah } \\
\hline & & & $0-2$ & $3-5$ & $6-8$ & $9-11$ & $12-45$ & \\
\hline 1 & 45000 & 180000 & - & 3 & 4 & 3 & 2 & 12 \\
\hline 2 & 180001 & 315000 & - & - & 5 & 6 & 5 & 16 \\
\hline 3 & 315001 & 450000 & - & - & 1 & 3 & 15 & 19 \\
\hline 4 & 450001 & 585000 & - & - & - & 2 & 1 & 3 \\
\hline 5 & 585001 & 720000 & - & - & 1 & - & 1 & 2 \\
\hline 6 & 720001 & 855000 & - & - & - & - & 3 & 3 \\
\hline 7 & 855001 & 990000 & - & - & - & - & 8 & 8 \\
\hline \multicolumn{3}{|c|}{ Total } & 0 & 3 & 11 & 14 & 35 & 63 \\
\hline
\end{tabular}

Tabel 3. Sistem Pembakaran Kendaraan

\begin{tabular}{clccc}
\hline No & Merek & Injeksi & Karburator & Jumlah \\
\hline 1 & Suzuki & 34 & 9 & 43 \\
2 & Toyota & 17 & 1 & 18 \\
3 & Mitsubishi & 1 & 1 & 2 \\
\hline & Jumlah & 52 & 11 & 63 \\
\hline
\end{tabular}

\section{Umur kendaraan}

Karakteristik umur kendaraan (Tabel 4). Tabel 4 memperlihatkan mayoritas kendaraan penumpang yang beroperasi di Kota Manokwari memiliki umur $\geq 12$ tahun sebanyak 35 kendaraan. Kendaraan paling tua berumur 28 tahun, sedangkan yang paling baru berumur 3 tahun. Tidak ada kendaraan penumpang yang berumur $<2$ tahun. Kendaraan dengan umur 3-5 tahun merupakan yang termuda berjumlah 3 kendaraan keluaran produsen Suzuki. Kendaraan produsen Mitsubishi keduanya memiliki umur $\geq$ 12 tahun.

\section{Perawatan}

Persentase kendaraan angkutan umum berdasarkan frekuensi perawatannya dapat dilihat pada Gambar 2. Mayoritas pemilik mobil sering melakukan perawatan mobil (54\%), sekitar $31,7 \%$ pemilik mobil kadangkadang melakukan perawatan dan hanya sekitar $14,3 \%$ pemilik mobil yang jarang melakukan perawatan. Gambar 2 menjelaskan bahwa mayoritas pemilik kendaraan sadar mengenai pentingnya melakukan perawatan terhadap kendaraan. Meskipun demikian dalam penelitian ini tidak diketahui kualitas perawatan yang dilakukan. Kualitas perawatan yang baik akan mengurangi kandungan emisi gas $\mathrm{CO}$ dan $\mathrm{CO}_{2}$, sebaliknya kualitas perawatan yang buruk akan menghasilkan kandungan emisi $\mathrm{CO}$ dan $\mathrm{CO}_{2}$ yang semakin besar (Rindani, 2011).

Tabel 4. Profil Umur Kendaraan

\begin{tabular}{ccccccccc}
\hline \multirow{2}{*}{ No } & \multirow{2}{*}{ Merek } & \multicolumn{7}{c}{ Umur (Tahun) } \\
\cline { 3 - 8 } & & $0-2$ & $3-5$ & $6-8$ & $9-11$ & $12-45$ & \\
\hline 1 & Suzuki & - & 3 & 9 & 7 & 24 & 43 \\
2 & Toyota & - & - & 2 & 7 & 9 & 18 \\
3 & Mitsubishi & - & - & - & - & 2 & 2 \\
\hline & Jumlah & - & 3 & 11 & 14 & 35 & 63 \\
\hline
\end{tabular}




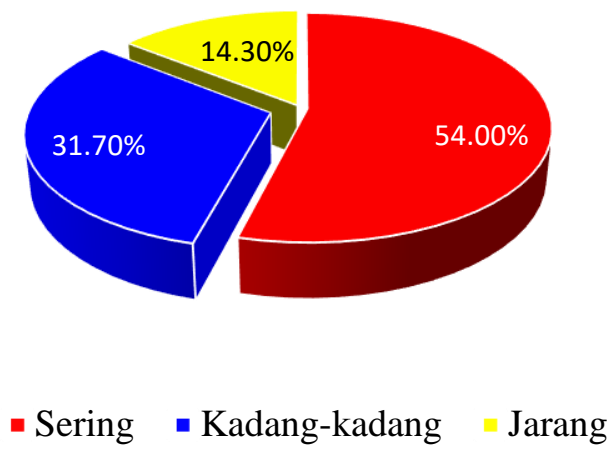

Gambar 2. Persentase kendaraan angkutan umum berdasarkan frekuensi perawatan

Konsentrasi $\mathrm{CO}, \mathrm{HC}, \mathrm{CO}_{2}$, dan $\mathrm{O}_{2}$ pada Emisi Gas Buang Kendaraan Angkutan Umum

Hasil penelitian menegaskan konsentrasi CO maksimal kendaraan angkutan umum berpenggerak cetus api di stasiun pemeriksaan Terminal Wosi (Tabel 5).

\section{Hasil Uji Emisi Gas Buang Pada Kendaraan Angkutan Umum Terhadap Pencemaran Udara}

Terdapat empat unsur yang diukur yaitu senyawa $\mathrm{HC}, \mathrm{CO}, \mathrm{CO}_{2}$ dan $\mathrm{O}_{2}$. Hasil uji emisi gas buang terhadap pencemaran udara kendaraan angkutan umum di Terminal Wosi Type B (Tabel 6). Data pada Tabel 6 memperlihatkan mayoritas angkutan umum yang diperiksa dalam penelitian ini tidak lulus uji emisi gas buang yaitu 40 kendaraan $(63,50 \%)$ dan hanya 23 kendaraan $(36,50 \%)$ yang lulus uji emisi gas buang. Hal ini menjelaskan bahwa mayoritas angkutan umum yang beroperasi di Kota Manokwari mengeluarkan emisi gas buang melebihi ambang batas yang telah ditetapkan dan berpotensi mencemari udara.

Tabel 5. Konsentrasi $\mathrm{CO}, \mathrm{HC}, \mathrm{CO}_{2}$ dan $\mathrm{O}_{2}$ pada Emisi Gas Buang Kendaraan Angkutan Umum

\begin{tabular}{llcccccc}
\hline \multirow{2}{*}{ No } & \multirow{2}{*}{ Indikator } & \multirow{2}{*}{$\mathrm{N}$} & \multicolumn{5}{c}{ Konsentrasi Emisi Gas Buang } \\
\cline { 5 - 8 } & & Range & Min & Max & Mean & StDev \\
\hline 1 & $\mathrm{CO}(\%)$ & 63 & 9,98 & 0,02 & 10,00 & 2,13 & 3,13 \\
2 & $\mathrm{CO}_{2}(\%)$ & 63 & 15,90 & 1,20 & 17,10 & 12,96 & 3,83 \\
3 & $\mathrm{HC}^{2}(\mathrm{ppm})$ & 63 & $2.847,00$ & 48,00 & 2895,00 & 534,60 & 561.40 \\
4 & $\mathrm{O}_{2}(\%)$ & 63 & 18,11 & 0.00 & 18,11 & 2,71 & 4,10 \\
\hline
\end{tabular}

Tabel 6. Hasil Emisi Gas Buang Pada Kendaraan Angkutan Umum Terhadap Pencemaran Udara Menurut kelompok Umur di Kabupaten Manokwari.

\begin{tabular}{|c|c|c|c|c|c|c|c|c|}
\hline \multirow{2}{*}{ No } & \multirow{2}{*}{ Hasil Uji } & \multicolumn{5}{|c|}{ Umur (Tahun) } & \multirow{2}{*}{ Total } & \multirow{2}{*}{$\begin{array}{c}\text { Nisbah } \\
(\%)\end{array}$} \\
\hline & & $0-2$ & $3-5$ & $6-8$ & $9-11$ & $12-45$ & & \\
\hline 1 & Tidak Lulus Uji & - & 2 & 7 & 11 & 20 & 40 & 63,50 \\
\hline 2 & Lulus Uji & - & 1 & 4 & 3 & 15 & 23 & 36,50 \\
\hline & Jumlah & - & 3 & 11 & 14 & 35 & 63 & 100,00 \\
\hline
\end{tabular}


Umur kendaraan tidak memiliki hubungan dengan hasil emisi gas buang, karena pada umur kendaraan 12-45 tahun terdapat $42,86 \%$ kendaraan yang lulus uji, menunjukkan tingkat lulus uji yang lebih tinggi jika dibandingkan kendaraan dengan umur 9-11 tahun dengan lulus uji $21,43 \%$, atau umur kendaraan 6-8 tahun dengan lulus uji $36,36 \%$ dan kendaraan umur 3-5 tahun terdapat $33,33 \%$ yang lulus uji. Hal ini diduga disebabkan oleh kondisi non teknis kendaraan misalnya terjadi kebocoran pada pipa pembuangan (knalpot) pada bagian bawah kendaraan sehingga asap tidak seluruhnya masuk ke dalam alat pada saat pengujian emisi. Selain itu perawatan kendaraan juga diduga memberikan kontribusi terhadap emisi kendaraan. Semakin rutin kendaraan melakukan servis maka akan membuat mesin selalu berada pada posisi top performance, sehingga menghasilkan pembakaran yang sempurna akan menghasilkan emisi yang rendah (Rindani, 2011).

\section{Kabon Monoksida (CO)}

Konsentrasi CO di udara per waktu dalam satu hari dipengaruhi oleh kesibukan atau aktivitas kendaraan bermotor. Semakin ramai kendaraan bermotor, semakin tinggi tingkat polusi CO di udara (Fardiaz, 1992). Nevers (2000) menjelaskan, bahwa tiga perempat dari $\mathrm{CO}$ yang masuk ke udara berasal dari aktivitas manusia terutama dari kendaraan bermotor yang menggunakan mesin internal engines (Bakeri, et al. 2012).

Yulianti et al., (2014) menjelaskan bahwa apabila gas $\mathrm{CO}$ terhisap ke dalam paru-paru akan mengikuti peredaran darah dan akan menghalangi masuknya oksigen $\left(\mathrm{O}_{2}\right)$ yang dibutuhkan oleh tubuh. Hal ini terjadi karena gas $\mathrm{CO}$ bersifat racun metabolis, ikut bereaksi secara metabolis dengan darah menjadi karboksihemoglobin (COHb) (Soemirat, 2009). Ikatan karboksihemoglobin jauh lebih stabil dari pada ikatan oksigen dengan darah (oksihemoglobin) (Tugaswati, 2008). Keadaan ini menyebabkan darah menjadi lebih mudah menangkap $\mathrm{CO}$ dan menyebabkan fungsi vital darah sebagai pengangkut oksigen terganggu (Mukono, 2003).

\section{Hidrokarbon (HC)}

Hidrokarbon (HC) yang diproduksi oleh manusia terbanyak berasal dari transportasi, sedangkan sumber lainnya dari pembakaran gas, minyak, arang, kayu, proses-proses industri, pembuangan sampah, kebakaran hutan dan sebagainya. HC dalam jumlah sedikit tidak begitu membahayakan kesehatan manusia, walau HC juga bersifat toksik. Sifat toksik $\mathrm{HC}$ akan lebih tinggi jika berupa bahan pencemar gas, cairan dan padatan. Hal ini karena padatan HC (partikel) dan HC (cairan) akan membentuk ikatanikatan baru dengan bahan pencemar lainnya (Tugaswati, 2008). Menurut Soedomo (2001), gangguan pernapasan timbul akibat senyawa hidrokarbon, seperti laryngitis, pharya dan brochitis.

Wardhana (2004) menyatakan bahwa Hidrokarbon (HC) adalah pencemar udara dapat berupa gas, cairan atau padatan. HC merupakan ikatan kimia dari karbon $(\mathrm{C})$ dan hidrogen $(\mathrm{H})$. Hidrokarbon terbentuk dari campuran bahan bakar yang tidak tercampur rata pada saat pembakaran, tidak bereaksi dengan oksigen, sehingga Hidrokarbon ini akan ikut keluar dengan gas buangan hasil pembakaran dan menjadi bahan pencemar udara. Sumber utama adalah gas buang dari kendaraan atau macammacam alat pembakaran lainnya (Sugiarta, 2008). Akibat yang ditimbulkan bila kepekatan HC bertambah tinggi akan merusak sistem pernapasan 
manusia (tenggorokan) terutama yang beracun adalah Benzena dan Toluene.

Profil umur kendaraan dan kondisi hasil uji emisi gas buang kendaraan digambarkan pada Gambar 3. Gambar 3 memperlihatkan bahwa pada setiap tingkatan umur kendaraan, jumlah kendaraan yang lulus uji seluruhnya lebih kecil jika dibandingkan dengan yang tidak lulus uji.

Inggris membuat kebijakan membatasi usia mobil selama 7 tahun sejak didaftarkan kepada otoritas setempat. Kebijakan ini mulai diimplementasikan pada 1 Januari 2018. Bagi mobil yang diregistrasi sebelum tanggal itu, tidak dikenakan pembatasan usia. Namun mobil yang tidak dikenakan pembatasan harus melewati uji kepatuhan kendaraan sesuai spesifikasi kendaraan yang layak jalan. Secara umum kebijakan pembatasan usia mobil di Inggris diberlakukan untuk menurunkan angka kemacetan dan mengontrol tingkat emisi gas buang mobil yang beredar di seluruh Inggris (Simmamora, 2006)

Di Indonesia baru Provinsi DKI Jakarta yang membatasi umur kendaraan bermotor. Itupun hanya sebatas mobil pribadi melalui Instruksi Gubernur No. 66 Tahun 2019 tentang Pengendalian Kualitas Udara. Instruksi gubernur tersebut salah satu butirnya menyebutkan mobil yang sudah berusia 10 tahun tidak dapat beroperasi di ibu kota. Selain itu mewajibkan kendaraan umum di wilayah Provinsi DKI Jakarta untuk melakukan uji emisi (Gubernur Provinsi DKI Jakarta, 2019).

\section{Analisis Faktor-Faktor Yang Mempengaruhi Emisi Gas Buang Kendaraan Angkutan Umum}

Emisi gas buang yang dianalisa terbatas pada $\mathrm{CO}$ dan $\mathrm{HC}$ yang merupakan persyaratan utama yang tertuang dalam Peraturan Menteri
Negara Lingkungan Hidup Nomor 4 Tahun 2009. Berikut hasil analisis faktor-faktor yang mempengaruhi emisi gas buang kendaraan angkutan umum (Menteri Negara Lingkungan Hidup, 2009).

\section{Karbon Monoksida (CO)}

Hasil analisis emisi gas buang Karbon Monoksida (CO) diperoleh nilai $\mathrm{R}^{2}$ sebesar 0,29. Nilai ini dapat diartikan bahwa keragaman emisi gas buang $\mathrm{CO}$ dapat dijelaskan oleh model sebesar $29 \%$ sedangkan $71 \%$, sisanya dijelaskan oleh variabel di luar model. Nilai korelasi ganda (R) sebesar 0,536 menjelaskan, bahwa terdapat keeratan hubungan yang sedang (Sugiyono, 2011) antara karakteristik kendaraan (X) yang meliputi: kapasitas silinder $\left(\mathrm{X}_{1}\right)$, panjang perjalanan $\left(\mathrm{X}_{2}\right)$, sistem pembakaran $\left(\mathrm{X}_{3}\right)$, umur kendaraan $\left(\mathrm{X}_{4}\right)$ dan perawatan kendaraan (X5) terhadap nilai emisi CO mobil penumpang di Terminal Wosi Type B Kabupaten Manokwari (Y). Hanya 2 variabel yang signifikan mempengaruhi model (Tabel 7) yaitu umur kendaraan $\left(\mathrm{X}_{4}\right)$ dan perawatan $\left(\mathrm{X}_{5}\right)$, sedangkan 3 variabel lainnya tidak signifikan mempengaruhi model.

Hasil penelitian menjelaskan
bahwa perawatan kendaraan berpengaruh terhadap kandungan emisi $\mathrm{CO}$, kendaraan dengan perawatan lebih baik memiliki kandungan emisi CO yang lebih rendah jika dibandingkan dengan kendaraan dengan perawatan jarang. Lupita (2013) menjelaskan bahwa semakin sering dilakukan servis pada sepeda motor maka besaran emisi $\mathrm{CO}$ yang dihasilkan akan semakin kecil. Demikian pula sebaliknya semakin jarang dilakukan servis pada sepeda motor maka semakin besar emisi CO yang dihasilkan. Periode servis kendaraan bermotor yang rutin dapat menghambat proses keausan yang akan memperlancar aliran udara dan bahan 
bakar sehingga terjadi peningkatan efisiensi kinerja mesin dan pembakaran yang terjadi sempurna dan konsentrasi emisi $\mathrm{CO}$ yang dihasilkan kecil (Purwani, 2004). Hasil uji F disajikan pada Tabel 8.

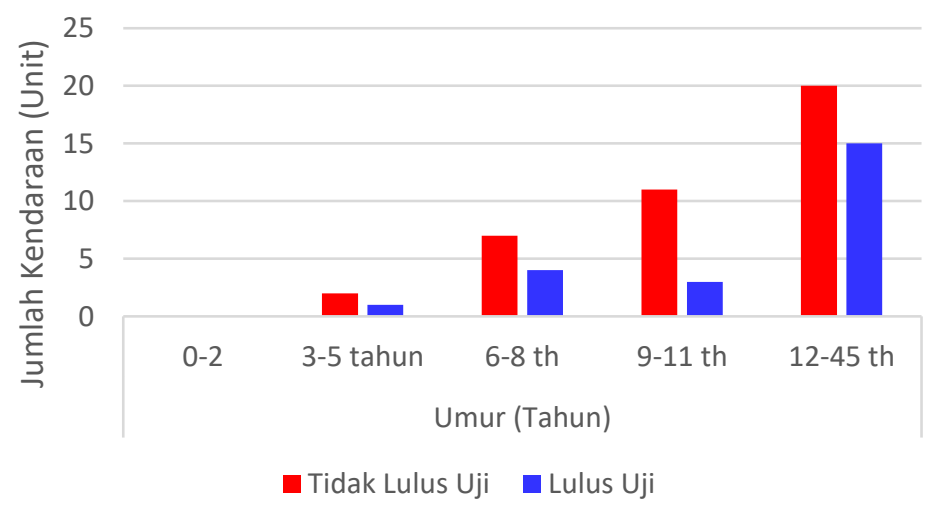

Gambar 3. Grafik Hubungan antara Hasil Emisi Gas Buang dan Umur Kendaraan

Tabel 7. Hasil Analisis Emisi Gas Buang CO

\begin{tabular}{|c|c|c|c|}
\hline No & Variabel & Koefisien & Sig \\
\hline 1. & Silinder $\left(\mathrm{X}_{1}\right)$ & 3,329 & $0,254^{\mathrm{ns}}$ \\
\hline 2. & Panjang Perjalanan $\left(\mathrm{X}_{2}\right)$ & $-0,000003$ & $0,135^{\mathrm{ns}}$ \\
\hline 3. & Sistem Pembakaran $\left(\mathrm{X}_{3}\right)$ & 0,772 & $0,614^{\mathrm{ns}}$ \\
\hline 4. & Umur Kendaraan $\left(\mathrm{X}_{4}\right)$ & 0,179 & $0,090 * *$ \\
\hline 5. & Perawatan $\left(\mathrm{X}_{5}\right)$ & 1,581 & $0.004 * * *$ \\
\hline
\end{tabular}

$\mathrm{R}=0,536, \mathrm{R}-\mathrm{Sq}=29 \%, \alpha=0,05$

$* * *$ Siginifikan pada $\alpha 1 \%, \mathrm{t}(57,1,674)$

**Siginifikan pada $\alpha 5 \%, \mathrm{t}(57,1,674)$

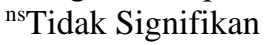

Model regresi linear berganda yang diperoleh adalah sebagai berikut :

$$
Y=-5,717+3,329 X_{1}-0,000003 X_{2}+0,772 X_{3}+0,179 X_{4}+1,581 X_{5}+\varepsilon
$$

Dimana:

$\begin{array}{llll}\mathrm{Y} & =\mathrm{CO}(\%) & \mathrm{X}_{1} & =\text { Silinder }(\mathrm{CC}) \\ \mathrm{X}_{2} & =\text { Panjang Perjalanan (KM) } & \mathrm{X}_{3} & =\text { Sistem Pembakaran } \\ \mathrm{X}_{4} & =\text { Umur Kendaraan (tahun) } & \mathrm{X}_{5} & =\text { Perawatan }\end{array}$

Tabel 8. Hasil Uji Koefisien Regresi Simultan (Uji F) untuk Emisi CO

\begin{tabular}{|c|c|c|c|c|c|c|c|c|}
\hline & Model & $\begin{array}{l}\text { Sum of } \\
\text { Squares }\end{array}$ & $\mathrm{df}$ & $\begin{array}{l}\text { Mean } \\
\text { Square }\end{array}$ & $\mathrm{F}$ & Sig. & $\mathrm{F}_{(5,57: 0.05)}$ & $\begin{array}{l}\text { Kesim- } \\
\text { pulan }\end{array}$ \\
\hline & Regression & 174,011 & 5 & 34,802 & 4,587 & $.001^{\mathrm{b}}$ & 2,38 & Signifikan \\
\hline \multirow[t]{2}{*}{1} & Residual & 432,485 & 57 & 7,587 & & & & \\
\hline & Total & 606,496 & 62 & & & & & \\
\hline
\end{tabular}


Tabel 8 menjelaskan, bahwa semua variable secara simultan (bersama-sama) mempengaruhi nilai emisi CO (Y). Hal ini dijelaskan melalui nilai F-hitung $(4,587)$ yang > nilai $\mathrm{F}$ tabel (2,38). Hasil penelitian ini menjelaskan bahwa seluruh variabel bebas yang digunakan dalam penelitian ini saling terkait satu dengan yang lainnya secara bersama-sama berpengaruh signifikan terhadap nilai CO.

\section{Hidro Karbon (HC)}

$\mathrm{R}^{2}$ hasil analisis emisi gas buang Hidro Karbon (HC) sebesar 0,631. Nilai tersebut dapat diartikan bahwa keragaman emisi gas buang $\mathrm{HC}$ dapat dijelaskan oleh model sebesar 63,10\% sedangkan $36,90 \%$ sisanya dijelaskan oleh variabel di luar model. Nilai Korelasi Ganda (R) sebesar 0,794 menjelaskan, bahwa terjadi hubungan yang kuat (Sugiyono, 2017) antara karakteristik kendaraan (X) yang meliputi: kapasitas silinder $\left(\mathrm{X}_{1}\right)$, panjang perjalanan $\left(\mathrm{X}_{2}\right)$, sistem pembakaran $\left(\mathrm{X}_{3}\right)$, umur kendaraan $\left(\mathrm{X}_{4}\right)$ dan perawatan kendaraan (X5) terhadap kandungan emisi $\mathrm{HC}$ pada mobil penumpang di Terminal Wosi Type B kabupaten Manokwari (Y). Tabel 9 memperlihatkan, bahwa terdapat 2 variabel yang signifikan mempengaruhi model yaitu silinder $\left(\mathrm{X}_{1}\right)$ dan perawatan $\left(\mathrm{X}_{5}\right)$, sedangkan 3 variabel lainnya tidak signifikan mempengaruhi model.

Hasil penelitian menjelaskan bahwa perawatan kendaraan berpengaruh terhadap kandungan emisi $\mathrm{CO}_{2}$, dimana kendaraan dengan perawatan lebih baik memiliki kandungan emisi $\mathrm{CO}_{2}$ yang lebih tinggi jika dibandingkan dengan kendaraan dengan perawatan jarang. Lupita (2013) menjelaskan bahwa, semakin rutin kendaraan melakukan servis maka nilai emisi karbon dioksida yang dihasilkan akan semakin tinggi. Karbon dioksida merupakan hasil sampingan dari pembakaran bahan bakar fosil dengan udara yang stokiometris, semakin rutin kendaraan melakukan servis maka nilai emisi karbondioksida yang dihasilkan semakin tinggi karena dengan melakukan perawatan mesin secara rutin akan membuat mesin selalu berada pada posisi top performance, sehingga menghasilkan pembakaran yang sempurna (Nur, 2015).

Tabel 9. Hasil Analisis Emisi Gas Buang HC

\begin{tabular}{llll}
\hline No & \multicolumn{1}{c}{ Variabel } & \multicolumn{1}{c}{ Koefisien } & \multicolumn{1}{c}{ Sig } \\
\hline 1. & Silinder $\left(\mathrm{X}_{1}\right)$ & 2131.819 & $0.000^{* * *}$ \\
2. & Panjang Perjalanan $\left(\mathrm{X}_{2}\right)$ & 0.0002 & $0.483^{\text {ns }}$ \\
3. & Sistem Pembakaran $\left(\mathrm{X}_{3}\right)$ & 283.935 & $0.154^{\text {ns }}$ \\
4. & Umur Kendaraan $\left(\mathrm{X}_{4}\right)$ & 17.940 & $0.184^{\text {ns }}$ \\
5. & Perawatan $\left(\mathrm{X}_{5}\right)$ & 207.704 & $0.003^{* * *}$ \\
\hline
\end{tabular}

$\mathrm{R}=0,794, \mathrm{R}-\mathrm{Sq}=63,1 \%$

$* * *$ Siginifikan pada $\alpha 1 \%, \mathrm{t}-(57,1,674)$

**Siginifikan pada $\alpha 5 \%, \mathrm{t}-(57,1,674)$

ns $=$ Tidak Signifikan

Model regresi linear berganda yang diperoleh adalah sebagai berikut :

$$
Y=-2.625,425+2.131,819 X_{1}+0,0002 X_{2}+283,935 X_{3}+17,940 X_{4}+207,704 X_{5}+\varepsilon
$$

Dimana :

$\begin{array}{llll}\mathrm{Y} & =\mathrm{HC}(\%) & \mathrm{X}_{1} & =\text { Silinder }(\mathrm{cc}) \\ \mathrm{X}_{2} & =\text { Panjang Perjalanan } \quad(\mathrm{km}) & \mathrm{X}_{3} & =\text { Sistem Pembakaran } \\ \mathrm{X}_{4} & =\text { Umur Kendaraan (tahun) } & \mathrm{X}_{5} & =\text { Perawatan }\end{array}$


Uji $\mathrm{F}$ dilakukan untuk mengetahui pengaruh karakteritik kendaraan angkutan umum meliputi: kapasitas silinder $\left(\mathrm{X}_{1}\right)$, panjang perjalanan $\left(\mathrm{X}_{2}\right)$, sistem pembakaran $\left(\mathrm{X}_{3}\right)$, umur kendaraan $\left(\mathrm{X}_{4}\right)$ dan perawatan kendaraan (X5) secara bersama-sama (simultan) terhadap nilai emisi HC (Y) (Tabel 10).

Tabel 10 menjelaskan, bahwa secara simultan (bersama-sama) mempe- ngaruhi nilai emisi $\mathrm{HC}(\mathrm{Y})$. Hal ini dijelaskan melalui nilai F-hitung $(19,470)>$ nilai F-tabel $(2,38)$. Hasil penelitian menjelaskan bahwa seluruh variabel bebas yang digunakan dalam penelitian ini saling terkait satu dengan yang lainnya secara bersama-sama berpengaruh signifikan terhadap nilai HC.

Tabel 10. Hasil Uji Koefisien Regresi Simultan (Uji F) untuk Emisi HC

\begin{tabular}{llccccccc}
\hline Model & Sum of Squares & df & Mean Square & F & Sig. & $\mathbf{F}_{(5,57: 0.05)}$ & $\begin{array}{c}\text { Kesim- } \\
\text { pulan }\end{array}$ \\
\hline & Regression & 12324482.950 & 5 & 2464896.590 & 19,470 & $.001^{\mathrm{b}}$ & 2,38 & Signifikan \\
1 & $\begin{array}{l}\text { Residual } \\
\text { Total }\end{array}$ & 7216030.129 & 57 & 126597.020 & & & & \\
\hline
\end{tabular}

a. Dependent Variable: HC

b. Predictors: (Constant), Perawatan, Umur, Silinder, Sistem_Pembakaran, Panjang_perjalanan

\section{KESIMPULAN}

Rata-rata besaran emisi gas buang kendaraan angkutan umum berpenggerak cetus api di Kabupaten Manokwari adalah $\mathrm{CO}=2,13 \%, \mathrm{HC}=$ 534,60 ppm, $\mathrm{CO}_{2}=12,96 \%$ dan $\mathrm{O}_{2}=$ $2,71 \%$. Mayoritas angkutan umum yang beroperasi di Kota Manokwari mengeluarkan emisi gas buang melebihi ambang batas yang telah ditetapkan dan berpotensi mencemari udara atau tidak lulus uji emisi $=63,50 \%$ dan $36,5 \%$ angkutan umum yang lulus uji emisi gas buang.

Secara simultan (bersama-sama) kapasitas silinder (X1), panjang perjalanan (X2), sistem pembakaran (X3), umur kendaraan (X4) dan perawatan kendaraan (X5) mempengaruhi nilai emisi $\mathrm{CO}$ dan $\mathrm{HC}(\mathrm{Y})$. Secara parsial terdapat dua karakterisktik kendaraan yaitu umur kendaraan (X4) dan perawatan kendaraan (X5) yang mempengaruhi nilai CO. Karakterisktik kendaraan yang mempengaruhi nilai $\mathrm{HC}$ secara parsial hanya ada dua: kapasitas silinder $\left(\mathrm{X}_{1}\right)$ dan perawatan kendaraan (X5).

\section{DAFTAR PUSTAKA}

Arafah, M., Selintung, M., Aly, S.H., dan Ramli, M.I. (2013). The Motorcycle Emission Characteristics in Developing Countries: Logit and Regression Analysis of I/M Data in Makassar City, Indonesia. Proceeding of the 10th Conference of the Eastern Asia Society for Transportation Studies.

Bakeri, M., A. Syarief dan A. Kusairi. (2012). Analisa Gas Buang Mesin Berteknologi Efi Dengan Bahan Bakar Premium. INFO TEKNIK, Volume 13 No. 1, Juli 2012.

Fardiaz, S. (1992). Polusi Air dan Udara. Yogyakarta: Kansius.

Gubernur Provinsi DKI Jakarta, (2019) Instruksi Gubernur No. 66 Tahun 2019 tentang Pengendalian Kualitas Udara. https://jdih.jakarta.go.id/himpunan /produkhukum_detail/9585 (diakses 03 Mei 2021)

Gunandi. (2010). Pengaruh Waktu Pengapian (Ignition Timing) Terhadap Emisi Gas Buang Pada 
Mobil Dengan Sistem Bahan Bahan Bakar Injeksi (EFI). Laporan Hasil Penelitian, www.digilib.its.ac.id Diakses pada tanggal

Hickman A J, (1999), Methodology for Calculating Transport Emissions and Energy Consumption, Transport Research Laboratory, Institut Teknologi Sepuluh November : Surabaya.

Lupita, C.P. (2013). Analisis Pengaruh Umur Mesin, Periode Servis dan Jarak Tempuh Terhadap Konsentrasi Emisi CO, Nox, HC dan CO2 Pada Sepeda Motor Tipe Sport (Studi Kasus : Motor Yamaha Vixion). Teknik Lingkungan Universitas Diponegoro : Semarang.

Menteri Lingkungan Hidup Republik Indonesia. (2010). Peraturan Menteri Nomor 12 tentang Pelaksanaan Pengendalian Pencemaran Udara. Jakarta : Menteri Negara Lingkungan Hidup.

Menteri Negara Lingkungan Hidup. (2006). Peraturan Menteri Negara Lingkungan Hidup Nomor 5 Tahun 2006 Tentang Ambang Batas Emisi Gas Buang Kendaraan Bermotor Lama. Jakarta : Menteri Negara Lingkungan Hidup.

Menteri Negara Lingkungan Hidup. (2009). Peraturan Menteri Negara Lingkungan Hidup Nomor 4 Tahun 2009 Tentang Ambang Batas Emisi Gas Buang Kendaraan Bermotor Tipe Baru. Jakarta : Menteri Negara Lingkungan Hidup.

Mukono, H.J. (2003). Pencemaran Udara dan Pengaruhnya terhadap Gangguan Saluran Pernafasan. Surabaya: Airlangga University Press.
Nevers, N., (2000). Air Pollution Control Engineering Second Edition. McGraw-Hill : Singapura.

Nur, I.A. (2015). Studi Karakteristik Emisi Kendaraan Ringan di Kota Makassar. Teknik Sipil: Universitas Hasanuddin.

Purwani, A., (2004). Studi Pengaruh Umur Mesin, Jarak Tempuh, dan Perawatan Kendaraan Bermotor Roda Empat Berbahan Bakar Bensin terhadap Konsentrasi Emisi CO (Studi Kasus: Kendaraan Instansi Kota Semarang). Teknik Lingkungan Universitas Diponegoro: Semarang.

Republik Indonesia. (2009). UndangUndang Republik Indonesia Nomor 22 Tahun 2009 Tentang Lalu Lintas dan Angkutan Jalan. Jakarta: Republik Indonesia.

Rindani, S., (2011). Analisis Pengaruh Umur Mesin dan Periode Servis Terhadap Konsentrasi Karbonmonoksida (CO) (Studi Kasus : Motor Matic Honda Vario). Teknik Lingkungan Universitas Diponegoro : Semarang.

Simmamora, A. P. (2006), "Garages ask speedier emission testing approval." The Jakarta Post-The Journal of Indonesia Today,City News. https//www.Thejakartapost.com May 012006.

Soedomo, M. (2001). Kumpulan Karya Ilmiah Pencemaran Udara. ITB

Soemirat, J. (2009). Kesehatan Lingkungan. Yogyakarta : Gadjah Mada University Press.

Sugiarta, A. A. G. (2008). Dampak Bising dan Kualitas Udara Pada Lingkungan Kota Denpasar. Jurnal Bumi Lestari, Vol. 8 No. 2. Universitas Udayana, Bali. 
Sugiyono, (2011). Metode Penelitian

Kuantitatif, Kualitatif dan R\&D. Bandung: Penerbit Alfabeta.

Syahrani, A., (2006). Analisa Kinerja Mesin Bensin Berdasarkan Hasil Uji Emisi. SMARTek. 4/4: 260266. Online. Available at http://jurnal.untad.ac.id/jurnal/ind ex.php/SMARTEK/article/downlo ad/446/383.

Tanan, B. (2011). Strategi Penanggulangan Pencemaran Udara dari sektor Transportasi. Adiwidia edisi Juni 2011.

Tugaswati, A. T. (2008). Emisi Gas Buang Kendaraan Bermotor dan Dampaknya Terhadap Kesehatan. Online. (http://www.kpbb.org). Diakses pada Minggu, 22 Mei 2016
Wardhana, W.A., (2004). Dampak Pencemaran Lingkungan. Penerbit Andi. Yogyakarta.

Wayunadjati, R., (2011). Analisis Pengaruh Jarak Tempuh, Periode Servis dan Umur Mesin Terhadap Konsentrasi CO, HC, Nox dan CO2 Pada Kendaraan Niaga (Studi Kasus: Motor Tossa). Teknik Lingkungan Universitas Diponegoro: Semarang.

Yulianti, S., Y. Fitrianingsih, dan D. R. Jati. (2014). Analisis Konsentrasi Gas Karbon Monoksida (CO) Pada Ruas Jalan Gajah Mada Pontianak. Jurnal Teknologi Lingkungan Lahan Basah. Vol 2, No 1 (2014). 